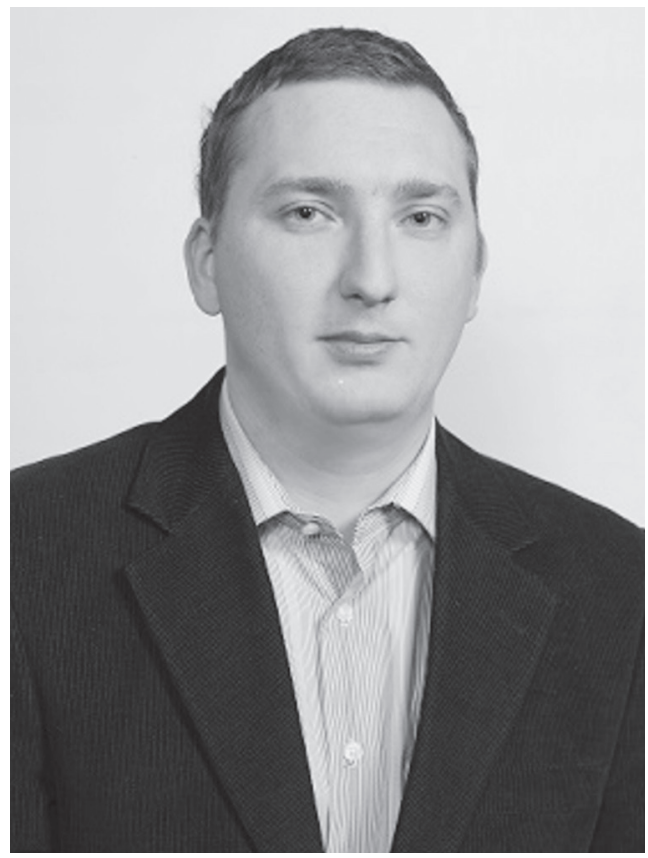

Omelyanenko Vitalii Anatoliyozych, PhD, Associate Professor, Associate Professor of Business Economics and Administration Department, Sumy State Pedagogical University named after A. S. Makarenko, 40002, Sumy, Romenskaia str., 87, tel.: +38 (095) 167 5952, e-mail: omvitaliy@gmail.com

ORCID: 0000-0003-0713-1444

\title{
АРХЕТИПНА СКЛАДОВА СТРАТЕГІЇ РОЗВИТКУ ІНСТИТУЦІЙНИХ МЕРЕЖ В КОНТЕКСТІ ЗАБЕЗПЕЧЕННЯ НАЦІОНАЛЬНОї БЕЗПЕКИ
}

Анотація. Актуальність дослідження безпекового аспекту процесів сьогодення та перспектив розвитку в рамках архетипної методології визначається тим, що системна трансформація суспільства вимагає точніше визначати чинники ряду процесів. Ця проблематика також актуалізується в контексті курсу на формування ефективного діалогу із суспільством, дослідження механізмів і способів поліпшення якості взаємодії держави, бізнесу та суспільства. Тому виникає необхідність розроблення теоретико-методологічних основ комплексної моделі організації взаємодії процесів індивідуального саморегулювання, корпоративного розвитку та державного управління на основі архетипного підходу. Метою дослідження є аналіз архетипної складової формування інституційних мереж у контексті безпекових стратегій. Інституціонально-мережевий підхід до безпекових стратегій припускає розгляд су- 
купності інститутів та закономірностей їх взаємодії в рамках активних мереж, що забезпечують перетворення ресурсів у реальні результати ефективними методами відповідно до національного контексту та запитів соціуму. Джерело відповідей на питання забезпечення безпеки запропоновано розглядати 3 точки зору архетипів. Підходи, викладені в дослідженні, грунтуються на розумінні того, що в сучасних умовах не можна обмежуватися традиційними методами управління та реагування на загрози національній безпеці. Визначено роль соціокультурних інститутів, що підвищується у сучасних умовах у вирішенні проблем в системі “безпека - розвиток”, з одного боку, і об’єктивна необхідність використання їх потенціалу - 3 іншого. Це зумовлює можливість включення архетипів у процеси забезпечення безпеки не лише на основі принципу додатковості, а й на паритетних засадах за рахунок розвитку їх взаємодії з формальними інститутами. Використання архетипного підходу сприятиме виробленню інноваційних підходів до розвитку безпекових стратегій за допомогою рішень, заснованих на комплексних дослідженнях і порядку денному в сфері публічної політики.

Ключові слова: національна безпека, архетип, інститут, мережа інститутів, стратегія.

\section{АРХЕТИПНАЯ СОСТАВЛЯЮЩАЯ СТРАТЕГИИ РАЗВИТИЯ ИНСТИТУЦИОННЫХ СЕТЕЙ В КОНТЕКСТЕ ОБЕСПЕЧЕНИЯ НАЦИОНАЛЬНОЙ БЕЗОПАСНОСТИ}

Аннотация. Актуальность исследования аспекта безопасности процессов настоящего и перспектив развития в рамках архетипной методологии определяется тем, что системная трансформация общества требует более точно определять факторы ряда процессов. Эта проблематика также актуализируется в контексте курса на формирование эффективного диалога с обществом, исследование механизмов и способов улучшения качества взаимодействия государства, бизнеса и общества. Поэтому возникает необходимость разработки теоретико-методологических основ комплексной модели организации взаимодействия процессов индивидуального саморегулирования, корпоративного развития и государственного управления на основе архетипного подхода. Целью исследования является анализ архетипной составляющей формирования институционных сетей в контексте стратегий обеспечения безопасности. Институционально-сетевой подход к стратегиям обеспечения безопасности предполагает рассмотрение совокупности институтов и закономерностей их взаимодействия в рамках активных сетей, которые обеспечивают превращение ресурсов в реальные результаты эффективными методами согласно национальному контексту и запросам социума. Источник ответов на вопрос обеспечения безопасности предложено рассматривать с точки зрения архетипов. Подходы, изложенные в исследовании, основываются на понимании того, что в современных условиях управления и реагирования на угрозы национальной безопасности нельзя ограничиваться традиционными методами. Определена роль социокультурных институтов, которая 
повышается в современных условиях в решении проблем в системе “безопасность - развитие”, с одной стороны, и объективная необходимость использования их потенциала - с другой. Это обусловливает возможность включения архетипов в процессы обеспечения безопасности не только на основе принципа дополнительности, но и на паритетных началах за счет развития их взаимодействия с формальными институтами. Использование архетипного подхода будет содействовать выработке инновационных подходов к развитию стратегий обеспечения безопасности с помощью решений, основанных на комплексных исследованиях и повестке дня в сфере публичной политики.

Ключевые слова: национальная безопасность, архетип, институт, сеть институтов, стратегия.

\section{ARCHITECTIC COMPONENT OF INSTITUTIONAL NETWORKS DEVELOPMENT STRATEGY IN THE CONTEXT OF NATIONAL SECURITY PROVIDING}

Abstract. The relevance of the study of the security aspects of the present processes and the prospects for development within the framework of the archetype methodology is determined by the fact that the systemic transformation of society requires a more precise determination of the factors of a number of processes. This issue is also actualized in the context of the course on forming an effective dialogue with the society, research of mechanisms and ways to improve the quality of interaction between the state, business and society. Therefore, it becomes necessary to develop the theoretical and methodological foundations of an integrated model for organizing the interaction of the processes of individual self-regulation, corporate development and public administration based on an archetype approach. The aim of the study is to analyze the archetypal component of the formation of institutional networks in the context of security strategies. Institutional-network approach to security strategies involves consideration of a set of institutions and the laws of their interaction within the framework of active networks that ensure the transformation of resources into real results by effective methods in accordance with the national context and the needs of society. The source of the answers to the question of security is proposed to consider from the point of view of archetypes. The approaches outlined in the study are based on the understanding that in modern conditions of government and responding to threats to national security cannot be limited to traditional methods. The role of sociocultural institutions has been determined, which rises in modern conditions in solving problems in the security-development system, on the one hand, and the objective need to use their potential, on the other. This makes it possible to include archetypes in the processes of ensuring security not only on the basis of the complementarity principle, but also on an equal footing due to the development of their interaction with formal institutions. Using an archetypal approach will help to develop innovative approaches to the development of security strategies through solutions based on comprehensive research and public policy agendas. 
Keywords: national security, archetype, institution, institutional network, strategy.

Постановка проблеми. Актуальність дослідження безпекового аспекту процесів сьогодення та перспектив розвитку в рамках архетипної методології визначається тим, що системна трансформація суспільства, побудова власної державності, коригування векторів зовнішньополітичної діяльності вимагає більш точно визначати чинники ряду процесів. Ця проблематика також актуалізується в контексті курсу на формування ефективного діалогу із суспільством. Дослідження механізмів i способів поліпшення якості взаємодії держави, бізнесу та суспільства $€$ актуальною науково-практичною проблемою.

Світовий досвід “стрибків” розвитку переконливо свідчить, що їх можна здійснити лише шляхом залучення та концентрації значного обсягу ресурсів, їх спрямування на пріоритетні напрями визначені на основі суспільного діалогу під координацією держави. У вітчизняній практиці переважно в якості ресурсів розглядають економічні (фінансові), нехтуючи при цьому факторами людської природи (фактори формування та використання соціального та людського капіталу), які є найважливішими в сучасних умовах.

Відтак поточна політико-економічна ситуація гостро ставить питання про пошук кращих форм та стратегій організації забезпечення безпеки як особистості, так і держави загалом при врахуванні національних особливостей. Незважаючи на те, що питання менталітету досить добре вивчені, однак в якості фактора забезпечення безпеки вони є важливими і актуальними об'єктами дослідження. Тому виникає необхідність розробки теоретико-методологічних основ комплексної моделі організації взаємодії процесів індивідуального саморегулювання, корпоративного розвитку та державного управління на основі архетипного підходу.

Аналіз досліджень та публікацій. Активна взаємодія соціокультурних інститутів та їх архетипної основи у вирішенні безпекових проблем обумовлює зміни як в управлінні цією взаємодією, так і в системі управління розвитком безпекових сфер за рахунок значного розширення їх спектра [1-3].

У дослідженні [4] слушно відзначається, що в контексті розроблення системних стратегій розвитку виникають проблеми наукового синтезу, зокрема синтезу спектра суспільних наук з акцентами на соціалізацію та гуманізацію економічної теорії. Історія економічних навчань демонструє явну тенденцію переходу від простих двовимірних моделей взаємодії та поведінки на ринку до більш складних, системних, до спроб врахувати соціальні аспекти поведінки, зокрема етику (ще Адам Сміт звертав на неї увагу).

Підгрунтям для такого синтезу може бути еволюція розуміння процесів суспільного розвитку. Вже 3 XVIII ст. народи починають трактуватися як колективні особистості, 
наділені індивідуальними "характерами” (Монтеск'є, Гердер) з відповідними наслідками. Трохи пізніше романтики розбудовують вчення про “дух народу" як задану форму відношення до світу та відповідну програму його історичної самореалізації [5].

Про необхідність вироблення нових моделей соціально-економічних процесів висловився й співзасновник Deepmind Мустафа Сулейман. Визнаючи успішність існуючого ладу (капіталізм й модерн), він підкреслює, що система стратегічно перестала служити на користь людству. Потрібні нові “форми розуму” та інструменти, що допоможуть розв’язати актуальні проблеми.

3 цієї точки зору архетипна складова формує нову площину аналізу, вводячи в оборот нові ресурси нематеріальної природи. Свого часу Адам Сміт наводив докази того, що поведінка людини приводить до народження нового порядку.

На думку відомого українського економіста М. Туган-Барановського, психологічні почуття людини, зокрема релігія, патріотизм, мораль, національний характер і самосвідомість та інші чинники нематеріальної природи, спроможні бути наймогутнішими силами розвитку економічної діяльності, а нематеріальні цінності - $€$ навіть більшим рушієм, аніж матеріальні потреби [6].

Окремі елементи архетипної методології знаходимо у вченні В. Вернадського про ноосферу, в рамках якого виживання цивілізації є можливим лише за умови гармонізації відносин людини, суспільства та природи як єдиного цілого на основі глобальності мислення та відповідальності людини за життєдіяльність (розуміння себе в світі). У дослідженні [7] відзначається, що вирішення проблем ноосферного суспільного відтворення має виходити з розуміння того, що людина включена не тільки в соціально-економічний, соціокультурний, інноваційний, суспільно-історичний, а й в еволюційний (генетичний) глобальний процес.

Розглянемо й можливість отримання ресурсів внаслідок врахування архетипів у межах безпекового аспекту. Отже, культура i, насамперед, менталітет та соціальні інститути можуть як сприяти, так і перешкоджати реалізації можливостей, закладених у ринкових відносинах і демократії [8].

Модель групової поведінки Хоуманса показує, що неформальні організації динамічно взаємодіють з формальними, впливають на прийняття різноманітних рішень. У сучасних умовах ця взаємодія відбувається у межах системи мережевих структур.

У рамках аналізу стратегічного аспекту відзначимо Мюрдаля [9] (представника напряму інституціоналізму), який підвищену увагу приділяє морально-етичним та соціальним факторам. Роль цих питань часто домінує над власне політичними й економічними проблемами. Одна 3 найважливіших ідей Мюрдаля це принцип загальної причинності, відповідно до якого будуються моделі взаємодії економічних та неекономічних (соціальних) змінних. За цими моделями можемо простежити тісний зв'язок між рівнями охорони здоров'я, освіти, соціальної допомоги та продуктивності. Включення в аналіз неекономічних змін- 
них відкриває можливості дослідження численних взаємозалежних процесів, для яких загальноприйнятий економічний аналіз непридатний.

Проведений аналіз досліджень показав, що безпековий компонент майже не розглядається у межах архетипного підходу, що призводить до втрати потенціалу протидії загрозам національній безпеці.

Метою дослідження $є$ аналіз архетипної складової формування інституційних мереж у контексті безпекових стратегій.

Методологія дослідження включає загальнонаукові методи аналізу й синтезу, історичного та логічного, системного та структурно-функціонального аналізу, імітаційного інституційно-еволюційного моделювання 3 метою максимізації ефектів синергіï у публічному управлінському просторі та системний підхід до його побудови.

Для вирішення широкого спектра оптимізаційних завдань будуть використані адаптовані методи ухвалення рішень на основі оптимізації показників ефективності, методи пошуку інноваційних шляхів розвитку, методи комплексного аналізу політики розвитку та методи проектного управління. При цьому необхідність залучення архетипної методології обумовлюється тим, що завдання комплексного реформування публічного управління мають вирішуватися 3 урахуванням національних особливостей кожної країни.

Інституціонально-мережевий підхід до безпекових стратегій припускає розгляд сукупності інститутів та закономірностей їх взаємодії у межах активних мереж, що забезпечують перетворення ресурсів у реальні результати ефективними методами відповідно до національного контексту та запитів соціуму. У дослідженні окремі аспекти вказаного підходу будуть вивчені в кейс-дослідженнях в якості прикладів провідного досвіду.

Методологія дослідження також грунтується на ідеях дослідників Копенгагенської школи, що докорінно вплинули на розвиток сучасних безпекових досліджень [10]:

- розширене розуміння поняття “безпека”, що більше не обмежується військовим дискурсом. Натомість розглядаються п’ять основних секторів, у яких питання безпеки виникають як найбільш значимі: військовий; політичний; екологічний; економічний та соцієтальний;

- дослідження безпеки виходять зі сфери міжнародних відносин, додавши їм максимально міждисциплінарний характер;

- розробили аналітичне поняття “секьюритизація”, яке допомагає у дослідженні того, як той або інший випадок може бути віднесений або не віднесений до питання безпеки.

У контексті цих ідей архетипна складова виступає новим аспектом аналізу інституційних взаємодій.

Виклад основного матеріалу. У сучасних умовах стратегії взаємодії відіграють особливу роль в організації соціосистем та дають змогу визначити нові сторони ряду процесів через синтез міждисциплінарного знання. На експертному рівні навіть було сформовано характерну рису рішень Індустрії 4.0 - “ефективність від взаємодіï”. Саме ця фраза часто є 
відправною точкою для оцінювання готовності суспільств до нових умов розвитку. Здатність взаємодіяти з іншими - швидко інтегруватися в мережеві комунікації або адаптуватися до нових умов, відкритість до такого роду взаємодій стають істотними факторами конкурентоспроможності, яка, своєю чергою, стає механізмом забезпечення безпеки.

У роботі [11] описано тенденції сучасної моделі інноваційного розвитку. Автори констатують, що за останній час вимоги до державної політики суттєво зросли, тому що глобальна конкуренція змінюе звичний стан речей. Необхідно зміцнювати національні та регіональні інноваційні системи на основі міжінституційної координації.

Наприклад, у США політика є скоординованою, державною ініціативою 3 мобілізації національних ресурсів для прискорення інноваційно-технологічних змін та утримання лідерства в глобальній конкуренції. У цих умовах постає питання вироблення національних стратегій, оскільки для України нова технологічна революція являє собою шанс для зміни ролі в глобальній економічній конкуренції, але держава поки не використовує повною мірою наявний інноваційний потенціал.

Наприкінці XX ст. безпекові системи США та Західної Свропи зазнали перетворень, спрямованих на реалізацію принципу “активного соціального партнерства”, що припускає інтеграцію суспільної активності в безпекову систему. Стали широко використовуватися такі підходи, як community policing (суспільна поліція), problem-oriented services (про- блемно-орієнтовані служби), служби превенції на рівні муніципалітету та громад, орієнтовані на партнерство у сфері безпеки тощо.

В Україні можемо відзначити “менталітет мовчання", оскільки численні опитування показують, що абсолютна більшість українців не повідомляють про корупцію, вважаючи, що це нічого не змінить. Для порівняння можна навести той факт, що у середньому 90 \% жителів Норвегії, Данії та Великобританії готові повідомляти владу про факти корупції.

Відповідно до просторово-географічної взаємодії соціальних інститутів, можемо виділити такі взаємопов'язані рівні безпеки - глобальну, міжнародну, національну, суспільну та особисту в єдину мережеву структуру, де вони мають рівноправне значення [12]. Таким чином, система національної безпеки - це функціональна система з взаємозалежними компонентами, серед яких для цілей нашого дослідження виокремимо:

- національні інтереси;

- загрози національній безпеці;

- національні цінності та архетипи;

- інституційну систему забезпечення національної безпеки.

Саме у межах останнього компонента варто розглянути мережевий аспект. Відповідно систему забезпечення національної безпеки можемо розглянути як структурно-організовану діяльність органів влади (мережа формальних інститутів), різних організацій, громадян (мережі неформальних інститутів), об’єднаних цілями та завданнями для запобігання, усунення та ліквідації зовнішніх та внутрішніх загроз. 
y Stanford Encyclopaedia of Philosophy [13] соціальний (суспільний) інститут визначається як "історично сформована чи створена цілеспрямованими зусиллями форма організації спільної життєдіяльності людей, існування якої диктується необхідністю задоволення соціальних, економічних, політичних, культурних або інших потреб суспільства в цілому або його частини".

Інститути являють собою структуру, яку люди накладають на свої відносини, визначаючи, таким чином, стимули розвитку. У випадку, коли виникає інституціональна мережа, ростуть і сумарні можливості [14].

Безпековий аспект впливу архетипів пропонуємо розглянути з точки зору капіталу, що формується в інституційних мережах та водночас впливає на їх еволюцію.
На рис. 1 показана схема формування інституційних мереж у контексті безпекового підходу, що враховує генерацію капіталу взаємодії, а також завдання та результат безпекового управління.

Відповідно до класичного підходу, викладеного у дослідженні [15], структурний капітал містить у собі клієнтський i організаційний капітал.

Клієнтський капітал являє собою цінність відносин з клієнтами. Організаційний капітал включає інноваційний капітал (переважно капітал інновацій) та процесний капітал, який являє собою інфраструктуру (інформаційні технології, робочі процеси тощо), тобто капітал, матеріалізований в ефективних внутрішніх процесах.

Складності побудови емпіричних моделей впливу інтелектуального

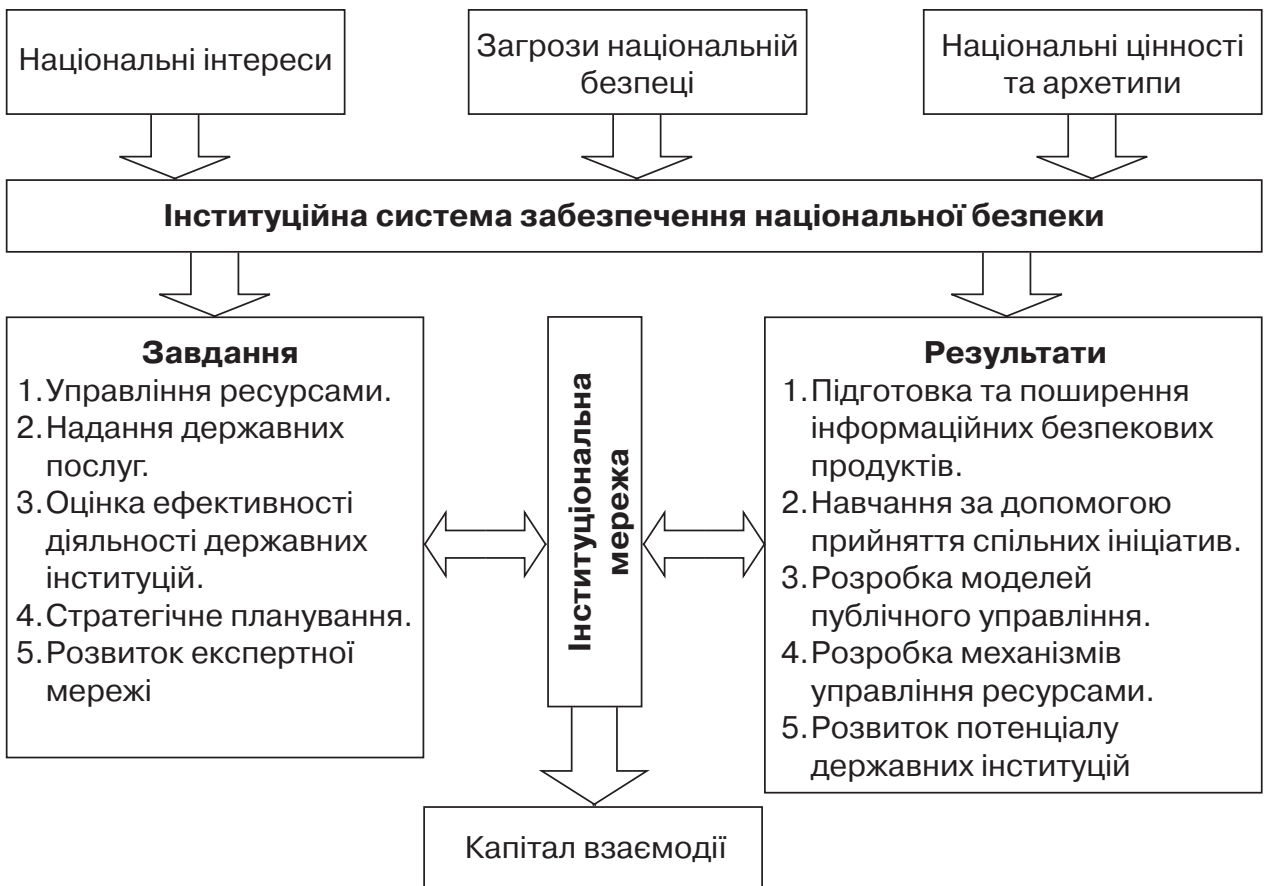

Рис. 1. Схема формування інституційних мереж у контексті безпекового підходу 
капіталу на результати діяльності пов'язані, насамперед, з його особливими властивостями, які необхідно враховувати при розробці гіпотез, виборі аналітичних методів, а також при інтерпретації отриманих результатів.

До таких характеристик інтелектуального капіталу можуть бути віднесені [16]:

- властивості суспільного блага не виключність і неконкурентність, що приводять до виникнення різнонаправлених результатів при використанні інтелектуального капіталу;

- здатність до відтворення, коли складові інтелектуального капіталу не втрачають своєї цінності при розподілі на частині, а збільшують їі при поширенні й обміні;

- невіддільність від носія (у випадку людського капіталу);

- суб'єктивність, яка означає, що цінність знань дуже залежить від контексту їх використання.

Розглядаючи структуру суспільства та формування ресурсів розвитку (капіталу), слід зазначити три базові інституційні рівні: політичний, економічний та соціокультурний (ментальний). Верхню частину структури утворюють політичні інститути, за допомогою яких реалізується обрана політична модель. Базову складову, на яку спираються політичні та економічні інститути, організують соціокультурні (ментальні) структури, що забезпечують внутрішню цілісність соціуму поряд з економічними інтересами та політичними уподобаннями. Вони, своєю чергою, у значній мірі визначаються сформованими на ментальному рівні соціокультурними нормами, традиціями, звичаями.

В основі системи забезпечення національної безпеки лежить концепція забезпечення національної безпеки, історична зміна якої тісно пов'язана з розвитком та становленням демократичних режимів [12]. Відповідно ключовими при аналізі концепцій забезпечення національної безпеки є такі питання: які з груп інтересів мають найбільший вплив при вибудовуванні ієрархії цілей; яким чином вони впливають на стан національної безпеки; чи існує партнерство між державою та суспільством у даному питанні; чи допускається суспільство в процес прийнять рішень щодо питань безпеки; чи $є$ цілі та завдання забезпечення національної безпеки результатом суспільного діалогу.

Інституціональна мережа здійснює поєднання різних процесів на мікро- і макрорівні. Бернейс [17], один з перших професіоналів у сфеpi PR в CША, визначає PR як сферу діяльності, що покликана займатися відносинами між особистістю, групою, ідеєю або іншою одиницею громадськості, від якої вона залежить.

Мережева взаємодія інститутів, що за своєю суттю засновані на соціокультурній (архетипічній) основі, виступає фактором розвитку вказаних компонентів національної безпеки, а вони, відповідно, впливають на характер і зміст взаємодії інститутів. У цьому контексті проблема досить часто полягає у протистоянні формальних і неформальних інститутів, що грунтується на архетипах.

Формальні інститути складаються переважно на основі існуючих не- 
формальних правил та механізмів. Структура формальних інститутів формується економічними, політичними інститутами, а також системою договорів.

Неформальні інститути є невід'ємною складовою сучасної структури суспільства. Вони функціонували задовго до трансформації у законодавчо та організаційно оформлені правила взаємодії. Причому різнонаправлений характер цих інститутів обумовив необхідність виникнення інститутів та організацій громадянського суспільства, що забезпечують реалізацію цих інтересів. Найважливіші функції неформальних інститутів - забезпечення взаємини держави, з одного боку, і бізнесу - з іншого.

Саме у недооцінюванні інституціональних проблем та їх природи полягає головна причина невдач i провалів реформування публічного простору. Відповідно до концепції Д. Норта [18] інститути обмежують та визначають спектр альтернатив, доступних економічним агентам, i впливають на їх рішення. На нашу думку, архетипічний підхід дає змогу конкретизувати причини вироблення альтернатив та успіх або невдачу при їх практичному втіленні.

Використання інституціонального підходу дає можливість подолати бар'єри, які не здатні подолати неокласичні теорії. У країнах з низьким рівнем розвитку соціальних інститутів, де відсутне довіра між владою, бізнесом і суспільством, економічні інститути не можуть одержати й раціонально використовувати ринкову інформацію, що зменшує темпи розвитку навіть при високій нормі інвестицій.
У дослідженні [19] показано, що розвинені країни з сильною економікою (зокрема Великобританія, Аргентина, КНР) покладають на інститути розвитку завдання перетворення депресивних або нерозвинених зон у простори для людей та бізнесу. У цьому випадку спеціально створені інститути розвитку є ефективним інструментом, оскільки вони акумулюють людський капітал (експертизу і компетенції), необхідний для розробки обгрунтованих у системному (органічному) змісті планів розвитку та їх втілення в реальність.

Архетипічною основою еволюції інститутів розвитку є критичність, що стимулює прогрес через виявлення оман та недоліків, щоб їх подолати. Наприклад, у конфуціанстві розроблений ідеал, який необхідно досягти і наявність якого неминуче призводить до критичного відношення до існуючої реальності. На основі цього у дослідженні [8], наприклад, зроблено висновок, що конфуціанство формує критичне мислення i таким чином сприяє соціальному прогресу.

Прикладом міждисциплінарного застосування синергетики може служити модель міграції. Зазначене питання досить болюче для ряду країн, що розвиваються. У ній проводиться відмінність між мікрорівнем індивідуальних рішень і макрорівнем динамічних колективних процесів у суспільстві. Макропроцеси описуються на рівні соціоконфігурацій, кожна з яких характеризується своїм вектором поведінки. Міграція в суспільстві також добре ілюструється комп'ютерними моделями з мінли- 
вими центрами, зумовленими нелінійними взаємодіями соціальних груп.

Відповідна мережева стратегія розглядає стійкість економічного росту як результат планомірного погодженого залучення сучасних конкурентних переваг (інноваційних, інформаційних та інтелектуальних) на всіх етапах ланцюжка створення вартості при участі ряду агентів та інститутів.

Безпекова стратегія орієнтує на погоджену роботу інститутів із забезпечення розвитку на основі ринкових механізмів, обміну інформацією та координацією дій, у які мають бути залучені державні структури різних рівнів, суспільні об'єднання та бізнес.

Мережа координації інститутів є багатосторонньою інституціональною платформою для безперервного обміну, моделювання та нарощення досвіду і знань за допомогою ство- рення експертної мережі у сфері розвитку публічного управління.

У контексті безпекових проблем зазначимо готовність інституційних мереж до протидії загрозам. Взаємодія інститутів, що має мережевий характер та враховує архетипічну структуру, може привести до створення мережевої соціокультурної організації, в основі якої лежить реалізація моделей взаємодії, що сприяють об'єднанню ресурсів та виробленню погоджених рішень (рис. 2).

Мережі забезпечують формування пропозицій щодо спільних дій 3 іншими інститутами, в пошуку зацікавлених інститутів та налагодженні взаємодії. Якщо у певному інституті відбуваються події, про них негайно інформують інших.

Фактор активних мереж на основі архетипів варто ураховувати в контексті того, що поступово знижується ефективність традиційних силових підходів безпекових стратегій.

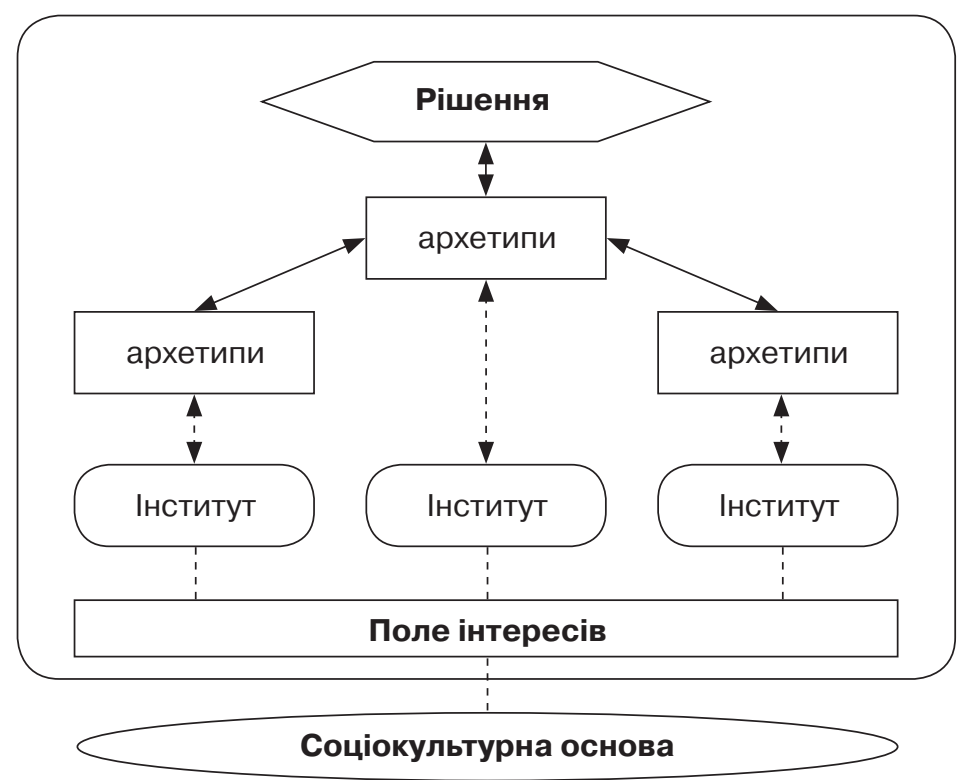

Рис. 2. Схема формування активної інституційної мережі 
На перший план у політиці все частіше стали виходити механізми “м'якої сили” (soft power), зокрема мережеві технології просування пріоритетів, формування інформаційного середовища, культурно-освітні програми, іміджеве конструювання тощо.

Формування мереж розвитку можемо розглянути 3 теоретичної складової еволюції громад міст та безпеки їх розвитку. На сьогодні міста є драйверами розвитку світової економіки й на них припадає до 80 \% внутрішнього валового продукту, що формується за рахунок концентрації людського капіталу та більш низькі транзакційні витрати.

Міста (громади) проходять такі стадії еволюції:

- Місто 1.0 - індустріальне місто, де розвинена промисловість, розміщені великі підприємства;

- Місто 2.0 - місто переходить більшою мірою до сфери послуг, розвитку малого та середнього бізнесу;

- Місто 3.0 - постіндустріальне місто, яке є центром освіти, технології, знань. Місто 3.0 - це також розвинена громадська ініціатива, що розвиває глобальну освіту, мультикультурність, міжнародну комунікацію та стає центром знань і технологій. Наприклад, у Лондоні лише 2 \% валового продукту формує промисловість. На перший план виходять фінансові ринки та економіка знань.

Наведена еволюція ілюструє зміни в базисі розвитку та зростання ролі саме соціокультурного чинника розвитку нових індустрій.

Також в якості мереж інститутів розвитку можемо розглянути співпрацю між університетами, бізнесом та суспільством. У межах цього до- цільно розглянути особливості стратегічної ролі академічних інституцій, зокрема в розрізі трьох основних місій: освітньої, дослідницької (наукової) та соціальної. Аналізуючи стан реалізації цих місій, можемо відзначити практичну відсутність системних процесів у двох останніх, що призводить до втрати потенціалу розвитку та погіршує реалізацію освітнього компоненту, який не пов'язаний з практикою.

Формування мереж інститутів не тільки сприяє ефективному трансферу знань, але також дає можливість вченим формулювати актуальні дослідницькі завдання, проводити високоякісні наукові дослідження та одержувати більш чітке уявлення про те, як застосовувати результати досліджень у галузях (тобто підвищити свою цінність та потенціал для інших інститутів). У цьому прикладі ми бачимо зростання цінності всіх наведених видів капіталу. Зазначений аспект може бути успішно використаний в інших сферах публічного управління.

\section{Висновки та перспективи подаль-} ших досліджень. Джерело відповідей на питання забезпечення безпеки запропоновано розглянути з точки зору архетипів. Підходи, викладені у дослідженні, грунтуються на розумінні того, що в сучасних умовах управління та реагування на загрози національній безпеці не можна обмежуватися традиційними методами, а необхідно враховувати ресурсний потенціал архетипної складової.

Визначено роль соціокультурних інститутів, що підвищується у сучасних умовах у вирішенні проблем в системі “безпека - розвиток”, з одно- 
го боку, і об'єктивна необхідність використання їх потенціалу - 3 іншого. Це зумовлює можливість включення соціокультурних інститутів у процеси забезпечення безпеки не тільки на основі принципу додатковості, а й на паритетних засадах за рахунок розвитку їх взаємодії з формальними інститутами, а також може стимулювати трансформацію державного управління за допомогою зміцнення й використання людського потенціалу та механізмів співробітництва.

Використання архетипного підходу сприятиме виробленню інноваційних підходів до розвитку безпекових стратегій за допомогою науково-обгрунтованих рішень, заснованих на комплексних дослідженнях і порядку денному у сфері публічної політики.

Подальші дослідження мають бути скеровані на аналіз конкретних інституційних мереж, що формуються (мають формуватися) для вирішення певних безпекових проблем.

\section{СПИСОК ВИКОРИСТАНИХ ДЖЕРЕЛ}

1. Bloksberg L., Mogulof D., Stern M., Walter F. Homans' Theory Of The Human Group: Applications To Problems of Administration, Policy, and Staff Training In Group Service Agencies // Journal of Jewish Communal Service: National Conference of Jewish Communal Service. 1964, p. 379-395.

2. National Security \& Innovation Activities: Methodology, Policy and Practice. edited by Dr. of Economics, Prof. O. Prokopenko, Ph.D in Economics V. Omelyanenko, Ph.D in Technical Sciences, Assoc. Prof. Yu. Ossik. -
Ruda Śląska: Drukarnia i Studio Graficzne Omnidium. 2018. 416 p.

3. Omelyanenko V.A. Archetypical analysis of the innovation development resources of European public administrative space (comparative approach) // Public management. 2018. - № 4 (14). - P. 198-212.

4. Яровий А. М. Методологічні інновації економічної науки в контексті переходу до нової парадигми постмодернізму // Регіональна бізнесекономіка та управління. - 2013. № 4. - C. 77-85.

5. Андреев А. Л. Политическая психология. - М.: Весь мир, 2002.

6. Гулевич О. Ю. Трудовий менталітет як інституціональний індикатор соціально-економічного розвитку суспільства // Наук. вісн. НАСОА. 2015. - № 1. - С. 35-42.

7. Никитенко П. Г. Ноосферная экономика как планетарная жизнедеятельностная хозяйственная сфера цивилизационного развития // Экономические и социальные перемены: факты, тенденции, прогноз. 2010. - № 3 (11). - URL: http://esc. volnc.ru/article/157

8. Якупов С. Ф. Менталитет и социальные институты как факторы прогресса: на примере индийской цивилизации // Вестн. Челябинского гос. ун-та. - 2013. - № 13 (304). Философия. Социология. Культурология. - Вып. 29. - С. $33-$ 40.

9. Мюрдаль Г. Азиатская драма: Исследование нищеты народов. - М., 1970. - $204 \mathrm{c}$.

10. Юрин А. Н. К понятию безопасность: кто и как определяет угрозу сегодня? // Regional Dialogue. 14.06.2016. URL: http://regional-dialogue.com/ $\mathrm{ru} /$ security/

11. Cervantes M., Meissner D. Commercialising Public Research under the Open Innovation Model: New 
Trends // Foresight. - 2014. - Vol. 8. - № 3. - P. 70-81.

12. Яшина А. В. Концепции обеспечения национальной безопасности в демократических государствах. - С.-Петерб. гос. ун-т. - СПб., 2013. - 237 с.

13. Social Institutions. Stanford Encyclopaedia of Philosophy. URL: https:// plato.stanford.edu/entries/social-institutions/

14. Dupont B. Security in the age of networks // Policing \& Society. 2004. - № 14 (1). - P. 76-91.

15. Эдвинсон Л. Корпоративная долгота: Навигация в экономике, основанной на знаниях. - М.: ИНФРА-М, 2005.

16. Tseng C.-Y., Goo Y.-J.J. Intellectual Capital and Corporate Value in an Emerging Economy: Empirical Study of Taiwanese Manufacturers // R\&D Management. - 2005. - Vol. 35. № 2. - P. 187-199.

17. Бернейс Э. М. Пропаганда. Нірро Publishing LTD, 2010. URL: https:// propagandahistory.ru/books/EdvardBerneys_Propaganda/

18. North D. Institutions and Economic Growth: An Historical Introduction / / World Development. - 1989. Vol. 17. - № 9. - P. 1319-1332.

19. Институты развития городов: успешные кейсы. URL: https://habr. com/ru/post/405343/

\section{REFERENCES}

1. Bloksberg L., Mogulof D., Stern M., Walter F. (1964). Homans' Theory Of The Human Group: Applications To Problems of Administration, Policy, and Staff Training In Group Service Agencies. Journal of Jewish Communal Service: National Conference of Jewish Communal Service, 379-395.

2. Prokopenko O., Omelyanenko V., Ossik Yu. (2018). National Security \& Innovation Activities: Methodology,
Policy and Practice. Ruda Śląska: Drukarnia i Studio Graficzne Omnidium.

3. Omelyanenko V. A. (2018). Archetypical analysis of the innovation development resources of European public administrative space (comparative approach). Public management, 4 (14), 198-212.

4. Yarozyi A. M. (2013). Metodolohichni innovatsii ekonomichnoi nauky v konteksti perekhodu do novoi paradyhmy postmodernizmu [Methodological innovations in economic science in the context of the transition to a new paradigm of postmodernism]. Rehionalna biznes-ekonomika ta upravlinnia Regional Business Economics and Management, 4, 77-85 [in Ukrainian].

5. Andreyev A. L. (2002). Politicheskaya psikhologiya [Political psychology]. Moscow: Ves Mir. [in Russian].

6. Gulevich O. Yu. (2015). Trudovyi mentalitet yak instytutsionalnyi indykator sotsialno-ekonomichnoho rozvytku suspilstva [Labor mentality as an institutional indicator of socio-economic development of society]. Naukovyi visnyk NASOA - NASOA Scientific Bulletin, 1, 35-42 [in Ukrainian].

7. Nikitenko P. G. (2010). Noosfernaya ekonomika kak planetarnaya zhiznedeyatelnostnaya khozyaystvennaya sfera tsivilizatsionnogo razvitiya [Noosphere economy as a planetary vital activity economic sphere of civilizational development]. Ekonomicheskiye i sotsialnyye peremeny: fakty, tendentsii, prognoz - Economic and social changes: facts, trends, forecast, 3 (11). Retrieved from http://esc.volnc.ru/article/157 [in Russian].

8. Yakupov S. F. (2013). Mentalitet i sotsialnyye instituty kak faktory progressa: na primere indiyskoy tsivilizatsii [Mentality and social institutions as factors of progress: the example of Indian civilization]. Vestnik Chelyabinskogo gosudarstvennogo univer- 
siteta - Bulletin of Chelyabinsk State University, 13(304). Filosofiya. Sotsiologiya. Kulturologiya, 29, 33-40. [in Russian].

9. Myurdal G. (1970). Aziatskaya drama: Issledovaniye nishchety narodov [Asian drama: A study of the poverty of nations]. Moscow [in Russian].

10. Yurin A. N. (2016). K ponyatiyu bezopasnost: kto i kak opredelyayet ugrozu segodnya? [On the concept of security: who and how determines the threat today?]. Regional Dialogue, 14.06.2016. Retrieved from http://regional-dialogue.com/ru/security/ [in Russian].

11. Cervantes M., Meissner D. (2014). Commercialising Public Research under the Open Innovation Model: New Trends. Foresight, Vol. 8, № 3, 70-81.

12. Yashina A. V. (2013). Kontseptsii obespecheniya natsionalnoy bezopasnosti $\mathrm{v}$ demokraticheskikh gosudarstvakh [Concepts of ensuring national security in democratic states]. Sankt-Peterburg: S.-Peterb. gos. un-t. [in Russian].

13. Social Institutions. Stanford Encyclopaedia of Philosophy. plato.stanford.edu. Retrieved from https:// plato.stanford.edu/entries/social-institutions/
14. Dupont B. (2004). Security in the age of networks. Policing \& Society, 14(1), 76-91.

15. Edvinson L. (2005). Korporativnaya dolgota: Navigatsiya $\mathrm{v}$ ekonomike. osnovannoy na znaniyakh [Corporate Longitude: Navigation in a Knowledge-Based Economy]. Moscow. INFRA-M [in Russian].

16. Tseng C.-Y., Goo Y.-J.J. (2005). Intellectual Capital and Corporate Value in an Emerging Economy: Empirical Study of Taiwanese Manufacturers. R\&D Management, Vol. 35. № 2, 187 199.

17. Berneys E. M. (2010). Propaganda [Propaganda]. Hippo Publishing LTD. Retrieved from https://propagandahistory.ru/books/Edvard-Berneys Propaganda/ [in Russian].

18. North D. (1989). Institutions and Economic Growth: An Historical Introduction. World Development, vol. 17, № 9, 1319-1332.

19. Instituty razvitiya gorodov: uspeshnyye keysy [Urban Development Institutions: Successful Case Studies]. habr.com. Retrieved from https:// habr.com/ru/post/405343/ [in Russian]. 